\title{
PERLINDUNGAN KONSUMEN TERHADAP PRAKTIK BISNIS EMITEN PENERBIT EFEK SYARIAH BERDASARKAN PRINSIP KETERBUKAAN \\ PASAR MODAL
}

\author{
Hari Rizki Satria \\ harisatria7@gmail.com
}

\begin{abstract}
ABSTRAK
Efek syariah merupakan surat berharga yang sesuai dengan prinsip-prinsip syariah di Pasar Modal. Efek syariah merupakan sarana investasi bagi umat islam yang ingin berinvestasi di Pasar Modal. Efek Syariah diterbitkan oleh emiten yang menjalankan kegiatan usahanya berdasarkan prinsip syariah dan telah mendapat penilaian Dewan Syariah Nasional Majelis Ulama Indonesia (DSN-MUI). Sebagai negara berpenduduk mayoritas muslim, efek syariah berperluang besar untuk berkembang pesat di Indonesia. Dalam rangka mengakomodir hal tersebut, konsumen selaku pemegang efek syariah harus mendapatkan kepastian hukum bahwasanya kegiatan bisnis yang dilakukan emiten penerbit efek syariah sesuai dengan prinsip syariah. Salah satu caranya yaitu melalui prinsip keterbukaan yang memberikan akses informasi kepada konsumen sebagai pemegang efek syariah untuk mengetahui secara berkala bahwasanya emiten penerbit efek syariah selalu menjalankan usahanya berdasarkan prinsip syariah.
\end{abstract}

Kata kunci: Efek Syariah, Perlindungan Konsumen, Prinsip Keterbukaan.

\begin{abstract}
Sharia securities are securities base on sharia principles at the Capital Market. The sharia securities are an investment mode for Muslims who want to invest their funds at capital markets. Sharia securities are issued by issuers whose businesses are based on sharia principles and assessed by the National Sharia Board of the Indonesian Ulema Council (Dewan Syariah Nasional-Majelis Ulama Indonesia or DSN-MUI). As a country with its dominant Muslim population, Sharia Securities have a great opportunity to develop quickly in Indonesia. In order to accommodate this condition, the holders of sharia securities must obtain legal certainty of that the business of sharia security issuers is managed in accordance with sharia principles. One of all, the business must apply the principle of transparency that enables the consumers to access corporate information. Consumer as an investor can earn enough information about business activities of issuers, especially whether it is run in accordance with shariah principles or not.
\end{abstract}

Keyword: Sharia securities, Consumer Protection, transparency 


\section{PENDAHULUAN}

Indonesia merupakan negara yang sedang membangun sehingga diperlukan adanya modal dan investasi yang besar. ${ }^{1}$ Setiap usaha penanaman investasi harus diarahkan kepada sektor kesejahteraan rakyat agar investasi yang ditanamkan investor dapat meningkatkan kualitas masyarakat Indonesia. ${ }^{2}$ Kegiatan Investasi yang berjalan baik dapat memberikan pengaruh besar terhadap perekonomian negara yang akhirnya berdampak pada kesejahteraan rakyat.

Salah satu bentuk kegiatan investasi adalah penanaman modal yang dilakukan di Pasar Modal. Pasar modal sama dengan pasar pada umumnya, yaitu tempat bertemunya antara penjual dan pembeli. ${ }^{3}$ Namun terdapat perbedaan dari segi objek yang diperjualbelikan yang mana hal yang diperjual belikan adalah surat berharga dalam bentuk saham, obligasi, reksa dana dll. Pasal 1 angka 13 UU No 8 Tahun 1995 tentang Pasar Modal berbunyi:

Pasar modal adalah kegiatan yang bersangkutan dengan Penawaran Umum dan Perdagangan Efek Perusahaan Publik yang berkaitan dengan efek yang diterbitkannya, serta lembaga dan profesi yang berkaitan dengan efek. ${ }^{4}$

Modal atau dana yang diperdagangkan didalam pasar modal diwujudkan dalam bentuk surat berharga atau dalam terminologi financial market disebut dengan efek berupa saham atau dalam bentuk surat berharga lainnya atau surat berharga yang merupakan derivatif dari bentuk berharga saham atau sertifikat yang diperjual belikan dipasar modal tersebut. ${ }^{5}$ Dari penjelasan diatas berhubungan dengan pasar modal, terdapat tiga unsur yang dapat dijabarkan berkaitan dengan kegiatan pasar modal, yaitu: ${ }^{6}$

> Penawaran Umum dan Perdagangan Efek.

$>$ Perusahaan publik yang berkaitan dengan efek yang diterbitkannya.

\footnotetext{
${ }^{1}$ Salim HS \& Budi Sutrisno, Hukum Investasi Di Indonesia, Cetakan Keempat, Rajawali Pers, Jakarta, 2014, hlm.1

${ }^{2}$ Ibid, hlm. 10

${ }^{3}$ Abdul R Saliman, Hukum Binis Untuk Perusahaan Teori dan Contoh Kasus, Cetakan Kesembilan , Prenamedia Grup, Jakarta, hlm.225

${ }^{4}$ Indonesia, Undang Undang tentang Pasar Modal, UU No 8 Tahun 1995, LN No.64 Tahun 1995, TLN No. 3608, Ps. 1 Angka 13

${ }^{5}$ M. Irsan Nasarudin dkk, Aspek Hukum Pasar Modal Indonesia, Cetakan Kedelapan, Kencana Prenadamedia Group, Jakarta, 2014, hlm.10

${ }^{6}$ Abdul R Saliman, op.cit., hlm.226
} 
$>$ Lembaga profesi yang berkaitan dengan efek.

Mengacu pada berbagai investasi dipasar modal, salah satu bentuk kegiatannya ialah melakukan pembelian efek syariah di pasar modal atau yang lazim dikenal dengan istilah pasar modal syariah. Pasar modal syariah adalah pasar modal yang dijalankan dengan prinsip syariah, setiap transaksi surat berharga di pasar modal dilaksanakan sesuai dengan ketentuan syariat islam. ${ }^{7}$ Pasar modal adalah salah satu sarana produk muamalah sehingga transaksi pasar modal, menuntut prinsip hukum syariah tidak dilarangan atau dibolehkan sepanjang tidak ada transaksi yang bertentangan dengan ketentuan yang telah digariskan syariah ${ }^{8}$

Saat ini, mulai tersedia berbagai produk pasar modal bagi umat islam untuk menanamkan uangnya dan bertransaksi di pasar modal islam. Produkproduk tersebut termasuk daftar sekuritas syariah yang sudah diakui oleh Komisi Syariah, Sekuritas Hutang Islam dan Indeks Syariah, jaminan-jaminan dan unitunit trust dalam islam. ${ }^{9}$ Unit trust islam merujuk pada pasar dimana kegiatan yang dilaksanakan tidak bertentangan dengan cara dan hati nurani umat islam dan ajaran islam. ${ }^{10}$ Dengan kata lain unit trust islam mencerminkan suatu pendirian hukum agama dalam transaksi pasar modal, dimana pasar harus bebas dari kegiatan yang terlarang oleh islam dan juga bebas dari elemen elemen misalnya riba (bunga), judi dan ghahar (mendua). ${ }^{11}$

Pada tahun 2004, perbandingan antara jumlah saham, obligasi dan reksadana konvensional dengan jumlah saham, obligasi dan reksadana syariah dapat dilihat berdasarkan tabel berikut: ${ }^{12}$

\footnotetext{
${ }^{7}$ Adrian Sutedi, Pasar Modal Syariah, Cetakan Petama, Sinar Grafika, Jakarta, 2011, hlm.29

${ }^{8} \mathrm{Ibid}$, hlm. 25

9 Mohd Ma'sum Billah, Penerapan Pasar Modal Islam, Sweet \& Maxwell Asia, Selangor, 2010, hlm.3

${ }^{10} \mathrm{Ibid}$

${ }^{11} \mathrm{Ibid}$

${ }^{12}$ Adrian Sutedi, op.cit., hlm.28
} 
Tabel 1

Perbandingan Produk Pasar Modal Konvensional dan Pasa Modal Syariah

\begin{tabular}{|c|c|c|c|c|c|}
\hline \multirow{2}{*}{ No } & \multirow{2}{*}{ Instrumen } & \multicolumn{2}{|c|}{ Produk Konvensional } & \multicolumn{2}{c|}{ Produk Syariah } \\
\cline { 3 - 6 } & & Jumlah & Nilai emisi & Jumlah & $\begin{array}{c}\text { Nilai } \\
\text { Emisi }\end{array}$ \\
\hline \multirow{2}{*}{1} & Saham & 418 & $\begin{array}{c}254.811 \\
\text { Triliun }\end{array}$ & 30 & $\begin{array}{c}0,233 \\
\text { triliun }\end{array}$ \\
\hline \multirow{2}{*}{2} & Obligasi & 145 & 75.055 & 10 & 1.117 \\
& & & Triliun & & triliun \\
\hline \multirow{2}{*}{3} & Reksadana & 209 & $\begin{array}{c}94.539 \\
\text { Triliun }\end{array}$ & 8 & Triliun \\
& & & & & \\
\hline
\end{tabular}

Sumber: data Bapepam \& BEJ

Data diatas menjelaskan tahun 2004 masih menunjukkan minat investasi pada produk syariah masih tertinggal jauh dibandingkan dengan produk konvensional. Namun saat ini, minat investasi di produk syariah mulai meningkat. Dibuktikan dengan di 2014, jumlah investor baru 2.705 orang. Sementara per September tahun ini, jumlahnya sudah mencapai 19.265 orang, naik 57 persen dibanding tahun sebelumnya. Jumlah tersebut setara 3,2 persen dari total investor di Indonesia. $^{13}$

${ }^{13}$ Aprilian Ika, BEI: Potensi Pasar Modal Syariah di Indonesia Masih Sangat Besar, http:// ekonomi. kompas.com/read/2017/10/30/063000926/bei--potensi-pasar-modal-syariah-diindonesia-masih-sangat-besar, diakses tgl 10 September 2019. 
Tabel 2

Perbandingan Investor Saham Syariah Setiap Tahun

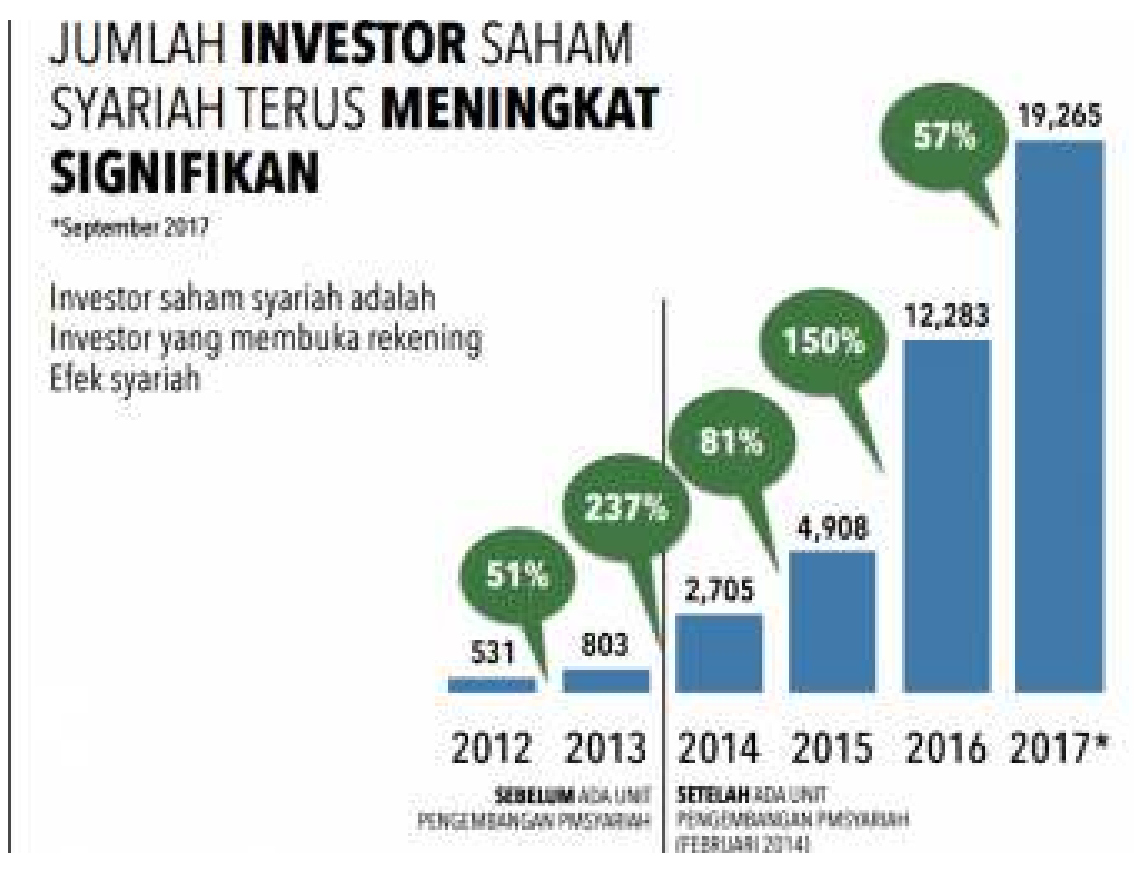

Jumlah Investor syariah(Dok. BEI)

Meningkatnya minat investasi disektor pasar modal syariah tentunya di tuntut memiliki instrumen hukum yang jelas dan pasti. Kejelasan instrumen hukum salah satunya dapat dilihat dari segi perlindungan konsumen selaku investor pada pasar modal syariah. Kepercayaan investor harus dijamin dengan prinsip keterbukaan sehingga mereka dapat mengetahui efek yang mereka miliki merupakan benar-benar efek dari perusahaan yang benar-benar menjalankan kegiatan usahanya berdasarkan prinsip syariah. Menjaga kepercayaan investor sangat penting bagi perkembangan Pasar Modal Syariah.

Dari sisi perlindungan konsumen, investor harus terdapat suatu kepastian hukum yang menjamin kegiatan emiten dalam menjalankan praktik bisnisnya tidak bertentangan dengan prinsip syariah. Hal Ini menjadi penting karena salah satu tujuan investor berinvestasi pada pasar modal syariah adalah untuk menghindari prkatik bisnis yang bertentangan dengan syariah islam. Perlindungan investor melalui Jaminan kepastian hukum sejatinya dapat diwujudkan dalam bentuk penerapan asas keterbukaan didalam kegiatan investasi yang dilakukan investor pada pasar modal syariah. Asas keterbukaan ini, terdapat pada penjelasan 
pasal 3 ayat 1 huruf b Undang Undang No 25 Tahun 2007 tentang Penanaman Modal (UU Penanaman Modal) yang berbunyi: ${ }^{14}$

asas keterbukaan yaitu: asas yang terbuka terhadap masyarakat untuk memperoleh informasi yang benar, jujur dan bertanggungjawab kepada masyarakat atau rakyat sebagai pemegang kedaulatan negara sesuai dengan ketentuan perundang undangan.

Selain itu penerapan prinsip keterbukaan ini merupakan salah satu upaya untuk mengakomodir hak konsumen sesuai ketentuan pasal 4 ayat 3 Undang Undang No 8 Tahun 1999 tentang Perlindungan Konsumen (UU Perlindungan Konsumen) yang berbunyi: ${ }^{15}$

\section{Hak konsumen adalah:}

1. hak atas informasi yang benar, jelas,dan jujur mengenai kondisi dan jaminan barang dan/atau jasa yang digunakan.

Melalui asas keterbukaan ini, diharapkan investor dapat memiliki akses informasi yang pasti dan jelas mengenai kegiatan bisnis emitennya apakah selalu menerapkan prinsip syariah atau tidak. Penerapan asas keterbukaan ini dalam rangka menghilangkan keragu-raguan investor untuk berinvestasi pada pasar modal syariah. Adanya jaminan kepastian hukum tersebut, maka minat investor berinvestasi pada pasar syariah dapat terus ditingkatkan sehingga mampu menunjang perekonomian nasional. Berdasarkan latar belakang di atas penulis tertarik melakukan Penelitian tentang "Perlindungan Konsumen Terhadap Praktik Bisnis Emiten Penerbit Efek Syariah Berdasarkan Prinsip Keterbukaan Pasar Modal"

Bertitik tolak dari uraian tersebut di atas, pertanyaan dalam penelitian adalah sebagai berikut:

\footnotetext{
${ }^{14}$ Indonesia, Undang-Undang tentang Penanaman Modal, UU No 25 Tahun 2007, LN 67 Tahun 2007, TLN 4724, Penjelasan Ps. 3 Ayat 1 Huruf b

15 Indonesia, Undang Undang Perlindungan Konsumen, UU No. 8 Tahun 1999, LN No. 42, Tahun 1999 TLN No. 3821, Ps. 4 Ayat 3
} 
1. Bagaimana Penerapan Prinsip Keterbukaan Didalam Pasar Modal Syariah

2. Bagaimana Perlindungan Konsumen Selaku Investor Terhadap Praktik Bisnis Emiten Didalam Pasar Modal Syariah

\section{Tinjuan Pustaka}

Pengenalan Pasar Modal Syariah memilikisifat krusial dalam rangka menyediakan ekonomi yang adil dan merata tanpa memandang ras, budaya adan agama. ${ }^{16}$ Terkhusus untuk islam, pasar modal yang berprinsip syariah sangat penting dalam rangka membuka peluang investasi. ${ }^{17}$ Islam tidak memperbolehkan harta kekayaan ditumpuk dan ditimbun karena hal-hal demikian adalah menyianyiakan ciptaan Allah SWT dari fungsi sebenarnya harta dan secara ekonomi akan membahayakan karena akan terjadi pemusatan kekayaan pada golongan tertentu saja. ${ }^{18}$

Terdapat dua hal utama yang menjadi perhatian didalam pasar modal syariah, yaitu indeks islam dan pasar modal syariah itu sendiri. Indeks islam menunjukkan pergerakan harga-harga saham yang dikategorikan sesuai dengan prinsip-prinsp syariah, sedangkan pasar modal syariah merupakan institusi pasar modal sebagaimana lazimnya yang diterapkan berdasarkan prinsip-prinsip syariah. ${ }^{19}$ Indeks islam tidak hanya dikeluarkan pasar modal syariah saja, melainkan juga oleh pasar modal konvensional. ${ }^{20}$ Di pasar modal indonesia, prinsip prinsip pernyataan modal secara syariah tidak diwujudkan dalam bentuk "saham syariah" maupun "saham non syariah" tetapi dalam bentuk indeks saham yang memenuhi prinsip-prinsip syariah yang dinamakan Jakarta Islamic Index (JII). ${ }^{21}$

${ }^{16}$ Mohd Ma'sum Billah, Penerapan Pasar Modal...., hlm.40

${ }^{17}$ Ahmad Nazir, S.Sos., M.Si Jurnal HUKAMUNA, Pasar Modal Syariah di Indonesia, Vol. 1 No. 2 Desember 2016.

${ }^{18}$ Ibid.

${ }^{19}$ Adrian Sutedi, op.cit., hlm.52

${ }^{20} \mathrm{Ibid}, \mathrm{hlm} .52-53$

${ }^{21}$ Iswi Hariyani \& Sefrianto Purnomo, Buku Pintar Hukum Bisnis Pasar Modal Strategi Tepat Investasi Saham, Obligasi, Waran, Right, Opsi, Reksadana, \& Produk Pasar Modal Syariah, visimedia, jakarta,2010, hlm.353 
JII yang berada di Bursa Efek Indonesia yang terdiri atas 30 saham perusahaan yang dinilai telah kriteria syariah yang ditetapkan oleh DSN-MUI ${ }^{22}$. Tujuan diadakannya indeks islam sebagaimana Jakarta Islamic Index adalah sebagai tolak ukur (bench mark) untuk mengukur kinerja investasi pada saham berbasis syariah dan meningkatkan kepercayaan investor untuk mengembangkan investasi dalam ekuiti secara syariah, atau untuk memberikan kesempatan kepada investor yang ingin melakukan investasi sesuai dengan prinsip syariah. ${ }^{23}$

Terdapat perbedaan mendasar antara indeks konvensional dengan indeks islam dari sisi saham yang tercatat dibursa. Indeks konvensional memasukkan seluruh saham yang tercatat dibursa dengan mengabaikan aspek halal haram, yang penting saham emiten yang terdafatar (listing) sudah sesuai aturan yang berlaku (legal). ${ }^{24}$ Sedangkan untuk indeks islam, terdapat kriteria-kriteria khusus berdasarkan syariah yang harus dipenuhi saham tersebut.

Di Indonesia terdapat jenis kegiatan usaha yang dikategorikan bertentangan dengan prinsip-prinsip syariah yaitu: ${ }^{25}$

1. Perjudian dan permainan yang tergolong judi atau perdagangan yang dilarang.

2. Menyelenggarakan jasa keuangan yang menerapkan konsep ribawi, jual beli risiko, mengandung gharar dan atau maysir.

3. Memproduksi, mendistribusikan, memperdagangkan dan atau menyediakan:

- Barang dan atau jasa yang haram karena zatnya (haram li dzatihi)

- Barang atau jasa yang haram bukan karena zatnya (haram li dzatihi) yang ditetapkan oleh DSN-MUI; dan atau

- Barang atau jasa yang merusak moral dan bersifat mudhorat

4. Melakukan investasi pada perusahaan yang pada transaksi tingkat (nisbah) atau perusahaan lembaga keuangan ribawi lebih dominan dari modalnya, kecuali investasi yang dinyatakan kesyariahannya oleh DSN-MUI.

Berdasarkan hal-hal diatas dapat ditarik garis pemisah antara indeks islam dan indeks konvensional. Pertama, jika indeks islam dikeluarkan oleh suatu institusi, yang bernaung dalam pasar modal konvensional, maka penghitungan indeks tersebut berdasarkan pada saham-saham yang digolongkan memenuhi

\footnotetext{
${ }^{22}$ Adrian Sutedi, op.cit., hlm.52

${ }^{23}$ Ibid.

24 Ibid.

${ }^{25}$ Iswi Hariyani \& Sefrianto Purnomo, op.cit., hlm.351-352
} 
kriteria syariah, sedangkan indeks konvensional memasukkan semua saham yang terdaftar dala bursa efek tersebut. Kedua, jika indeks islam dikeluarkan oleh institusi pasar modal syariah maka indeks tersebut didasarkan pada seluruh saham yang terdaftar didalam pasar modal syariah yang sebelumnya sudah diseleksi oleh pengelola. ${ }^{26}$

Penerapan prinsip syariah cukup efektif dalam meningkatkan minat investor yang ingin berinvestasi dalam rangka menghindari praktik bisnis yang haram. Namun dukungan dari pemerintah dari bentuk sosialisasi dan dorongan untuk berinvestasi pada pasar modal syariah masih dirasakan belum optimal. Ini dibuktikan dengan ungkapan Kepala Eksekutif Pengawas Pasar Modal OJK, Nurhaida yang menyatakan partisipasi masyarakat Indonesia untuk berinvestasi di pasar modal syariah juga masih minim yaitu $0,2 \%$ dari total penduduk Indonesia. ${ }^{27}$ Selain itu pemahaman berbagai pelaku usaha masih minim terkait dengan penerapan prinsip syariah didalam aktifitas bisnis. Sehingga bukan hal mustahil jika ada perusahaan yang masuk dalam list Daftar Efek Syariah (DES) dapat keluar dari list tersebut.

\section{METODE PENELITIAN}

\section{Jenis Penelitian}

Penelitian ini menggunakan pendekatan yuridis normatif, yaitu penelitian hukum yang dilakukan dengan cara meneliti bahan pustaka atau data sekunder. ${ }^{28}$ Penelitian ini mengkaji norma hukum yang berhubungan dengan perlindungan konsumen dikaitkan dengan perannya sebagai investor di Pasar Modal Syariah berdasarkan prinsip keterbukaan pasar modal.

${ }^{26}$ Adrian Sutedi, op.cit., hlm.54-55

${ }^{27}$ Ardan Adhi Chandra, Investasi Syariah Masih Minim, OJK Sosialisasi ke Pengajian Hingga Pesantrean, https://inance.detik.com/bursa-dan-valas/d-3233387/investasi-syariah-masihminim-ojk-sosialisasi -ke-pengajian-hingga-pesantren, diakses 10 September 2019

${ }^{28}$ Soerjonoe Soekanto dan Sri Mamudji. Penelitian Hukum Normatif: Suatu Tinjauan Singkat. (Jakarta:Rajagrafindo Persada, 2003), hlm. 13 


\section{Rancangan Penelitian}

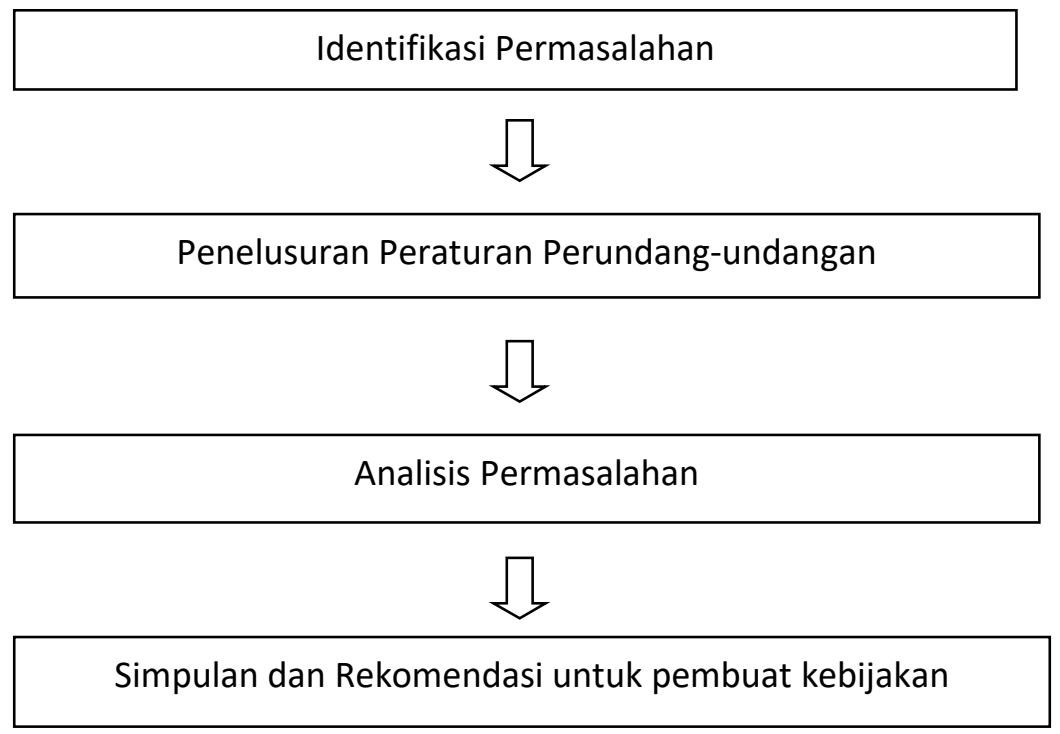

\section{Cara Penetapan dan Sampel Penelitian}

Populasi penelitian ini adalah hukum positif terkait dengan pasar modal syariah di Indonesia. Sample ditetapkan dengan pemilihan sampel yang bertujuan (purposive sampling). Sampel penelitiannya adalah peraturan perundangundangan yang terkait dengan pasar modal syariah

\section{Jenis Data}

Dalam konteks kajian hukum normatif ini, bahan yang dipergunakan adalah data-data sekunder yang terdiri dari :

a. Bahan Hukum Primer, yakni bahan bahan hukum yang mengikat. ${ }^{29}$ Dalam hal ini, yang akan diteliti adalah peraturan perundang undang dibidang pasar modal dan perlindungan konsumen.

b. Bahan Hukum Sekunder, yakni dokumen-dokumen pendukung bahan hukum primer yang memberikan informasi mengenai bahan hukum primer dan implementasinya. ${ }^{30}$ Bahan hukum sekunder memberikan penjelasan mengenai bahan hukum primer misalnya Rancangan Undang Undang,

\footnotetext{
${ }^{29}$ Bambang Sugono, Metodologi Penelitian Hukum, (Jakarta: Raja Grafindo Persada, 2007), hlm. 113

30 Sri Mamudji, Metode Penelitian dan Penulisan Hukum, (Jakarta: Badan Penerbit Fakultas Hukum Universitas Indonesia, 2005), hlm 28.
} 
Rancangan Peraturan Pemerintah, hasil penelitian, hasil karya ilmiah dari kalangan hukum. ${ }^{31}$

c. Bahan Hukum Tersier, yakni bahan bahan yang memberi petunjuk maupun penjelasan mengenai bahan hukum primer dan skunder misalnya kamus kamus hukum, ensiklopedia, indeks komulatif. ${ }^{32}$

\section{Instrumen Pengumpulan Data}

Penelitian hukum normatif adalah penelitian kepustakaan sehingga pengumpulan datanya adalah dengan melakukan studi kepustakaan.

\section{Analisis Data}

Analisis data dilakukan secara deskriptif analitis. Data yang terkumpul selanjutnya diolah, disistematisir sesuai dengan urutan permasalahan dan dianalisis. Data yang diperoleh disajikan secara kualitatif.

\section{HASIL PENELITIAN}

\section{Penerapan Prinsip Keterbukaan Didalam Pasar Modal Syariah}

Prinsip keterbukaan (full disclosure) dianut oleh seluruh pasar modal di dunia. $^{33}$ Prinsip full disclosure ini bermakna sebagai kewajiban emiten, perusahaan publik, atau siapa saja yang terkait untuk mengungkapkan informasi secara jelas, seakurat, dan selengkap mungkin mengenai fakta material yang berkaitan dengan tindakan perusahaan atau efeknya yang berpotensi kuat mempengaruhi keputusan pemegang saham atau calon investor terhadap saham. ${ }^{34}$ Sebagian besar peraturan pasar modal menekankan pada aspek keterbukaan atau trasnsparansi. ${ }^{35}$ Manajemen perusahaan sejak akan menjual efeknya kepada masyarakat sudah diwajibkan untuk mengungkapkan informasi perusahaan secara akurat antara lain: tujuan perusahaan, kegiatan usaha, keuangan, kinerja perusahaan, risiko material, dan kepemilikan hal hal lain yang mempunyai pengaruh terhadap perusahaan. ${ }^{36}$ Kewajiban itu terus berlanjut setelah perusahaan

\footnotetext{
${ }^{31}$ Bambang Sugono, op.cit., hlm, 114

${ }^{32}$ Ibid.

${ }^{33}$ Rafles, Inovatif Jurnal Ilmu Hukum, Analisis Penerapan Prinsip Keterbukaan di Pasar Modal Dalam Kaitannya Dalam Pengelolaan Perusahaan Yang Baik, Vol 8 No 1, 15 Maret 2016

${ }^{34}$ Ibid.

${ }^{35}$ M. Irsan Nasarudin dkk, op.cit., hlm.107

${ }^{36}$ Ibid
} 
menjadi perusahaan terbuka melalui penyampaian laporan berkala atau laporan yang bersifat insidentil untuk menjaga kualitas informasi yang akurat dan wajar, ${ }^{37}$

Pada pasar modal syariah penerapan prinsip keterbukaan adalah sama halnya dengan prinsip keterbukaan yang dianut didalam pasar modal konvensional. Hal ini sebagaimana yang dijelaskan didalam penjelasan Pasal 3 UU Penanaman Modal bahwa asas keterbukaan yaitu:

asas yang terbuka terhadap masyarakat untuk memperoleh informasi yang benar, jujur dan bertanggungjawab kepada masyarakat atau rakyat sebagai pemegang kedaulatan negara sesuai dengan ketentuan perundang undangan.

Mengacu pada ketentuan yang ada, pelaksanaan prinsip keterbukaan di pasar modal dilakukan melalui tiga tahap yaitu: ${ }^{38}$

a. Keterbukaan informasi pada saat melakuka penawaran umum (primary market level) yang didahului dengan pengajua Pernyataan Emisi ke Bapepam dengan menyerahkan semua dokumen penting yang dipersyaratkan dalaam peraturan IX.C.1 tentang pedoman Bentuk dan Isi Pernyataan Pendafataran.

b. Keterbukaan setelah emiten mencatat dan memperdagangkan efeknya di bursa (secondary market level). Dalam hal ini emiten wajib menyampaikan laporan keuangan secara berkala dan terus menerus (continiusly disclosure) kepada Bapepam dan Bursa.

c. Keterbukaan karena terjadi peristiwa penting dan laporannya harus disampaikan secara tepat waktu (timely disclosure) yakni peristiewa yang dirinci dalam Peraturan Nomor X.K.1.

Namun, terdapat sedikit perbedaan dalam implementasi prinsip keterbukaan antara pasar modal konvensional dengan pasar modal syariah. Perbedaan tersebut terdapat pada ketentuan pasar modal syariah yang menerapkan adanya keterbukaan dalam memberikan akses informasi mengenai suatu kegiatan usaha bisnis emiten yang tidak bertentangan dengan prinsip syariah.

Emiten adalah perusahaan yang menawarkan efeknya kepada masyarakat melalui penawaran umum (pasar perdana) dalam rangka menjaring dana bagi

\footnotetext{
${ }^{37}$ Ibid

${ }^{38}$ Irsan Nasarudin dkk, op.cit., hlm 229-230
} 
kegiatan usaha perusahaan. ${ }^{39}$ Emiten wajib menyampaikan informasi secara lengkap dan akurat. Informasi dikatakan lengkap jika disampaikan utuh, tidak ada yang tertinggal atau disembunyikan, disamarkan, atau tidak menyampaikan apaapa atas fakta material. ${ }^{40}$ Transaparansi atau keterbukaan informasi adalah suatu bentuk perlindungan kepada masyarakat investor. Dari segi substansial, transparansi memampukan publik untuk mendapatkan akses informasi penting yang berkaitan dengan perusahaan. Suatu pasar modal dikatakan fair dan efisien apabila semua pemodal memperoleh informasi dalam waktu yang bersamaan disertai kualitas informasi yang sama (equal treatment dalam akses informasi). ${ }^{41}$

Di Indonesia, prinsip-prinsip pernyataan modal secara syariah tidak diwujudkan dalam bentuk saham syariah maupun non syariah, melainkan berupa pembentukan indeks saham yang memenuhi prinsip prinsip syariah. Dalam hal ini, di Bursa Efek Indonesia terdapat Jakarta Islamic Indeks (JII) yang merupaka 30 saham yang memenuhi kriteria syariah yang ditetapkan Dewan Syariah Nasional (DSN). ${ }^{42}$ Saham saham yang masuk dalam indeks syariah adalah emiten yang kegiatan usahanya tidak bertentangan dengan syariah yaknu kegiatan usaha yang berada diluar kriteria bisnis berikut ini: ${ }^{43}$

a. Usaha perjudian dan permainan yang tergolong judi atau perdagangan yang dilarang

b. Usaha lembaga keuangan konvensional (ribawi) termasuk perbankan dan asuransi konvensional

c. Usaha yang memproduksi, mendistribusi serta memperdagangkan makanan dan minuman yang tergolong haram

d. Usaha yang memproduksi, mendistribusi dan/atau menyediakan barangbarang ataupun jasa yang merusak moral dan bersifat mudhorat.

Dalam hal keterbukaan informasi selanjutnya adalah adanya fatwa-fatwa yang dikeluarkan (Dewan Syariah Nasional) DSN terkait dengan emiten emiten yang masuk dalam kategori perusahaan yang menjalanan kegiatan bisnisnya berdasarkan prinsip syariah. Dewan Syariah Nasional (DSN) atau Al-Hai'ah as-

\footnotetext{
${ }^{39}$ Abdul R Saliman, op.cit., hlm.244

${ }^{40}$ Irsan Nasarudin dkk, op.cit., hlm.226

${ }^{41}$ Ibid

${ }^{42}$ Adrian Sutedi, op.cit., hlm.63-64

${ }^{43}$ Ibid, hlm. 64
} 
Syar'iyah al Wathaniyah (National Sharia Board) adalah lembaga yang berada dibawah Majelis Ulama Indonesia (MUI) yang memiliki tugas untuk menggali, mengkaji dan merumuskan nilai dan prinsip-prinsip hukum islam (syariah) sebagai dasar pedoman kegiatan tansaksi transaksi lembaga keuangan syariah serta mengawasi pelaksanaan dan implementasinya. ${ }^{44}$

Adapun inti dari fatwa DSN MUI dapat dilihat dari tabel dibawah ini: ${ }^{45}$

Tabel III

fatwa DSN MUI terkait emiten di Pasar Modal Syariah

\begin{tabular}{|c|c|c|}
\hline No & Soal & Keterangan \\
\hline 1 & Kriteria Emiten & $\begin{array}{l}\text { - Emiten yang akan menerbitkan efek } \\
\text { syariah dilarang menjalankan usaha yang } \\
\text { bertentangan dengan prinsip syariah } \\
\text { diantaranya perjudian, produksi dan } \\
\text { distribusi makanan atau minuman haram, } \\
\text { penyedia barang barang yang merusak } \\
\text { moral } \\
\text { - Emiten wajib memenuhi ketentuan akad } \\
\text { sesuai dengan gaya dan efek syariah yang } \\
\text { telah dikeluarkan } \\
\text { Wajib memiliki Syariah Compilence } \\
\text { Officer }\end{array}$ \\
\hline 2 & $\begin{array}{l}\text { Kriteria dan jenis } \\
\text { efek syariah }\end{array}$ & $\begin{array}{l}\text { Terdiri dari:saham syariah, obligasi syariah, } \\
\text { reksadana syariah, Kontrak Investasi kolektif } \\
\text { Efek Beragun Aset (KIK EBA) Syariah dan surat } \\
\text { berharga lainnya. }\end{array}$ \\
\hline 3 & $\begin{array}{l}\text { Transaksi yang } \\
\text { dilarang }\end{array}$ & $\begin{array}{l}\text { Dilarang melakukan transaksi yang mengandung } \\
\text { spekulasi, manipulasi yang didalamnya }\end{array}$ \\
\hline
\end{tabular}

${ }^{44} \mathrm{Ibid}, \mathrm{hlm} .83$

${ }^{45} \mathrm{Ibid}, \mathrm{hlm} .83-84$ 


\begin{tabular}{|l|l|l|}
\hline \multirow{2}{*}{} & & $\begin{array}{l}\text { mengandung unsur dhahar, ghahar, riba, maisir, } \\
\text { risywah, maksiat, dan kezhaliman, Contohnya } \\
\text { penawaran palsu, perdagangan orang dalam, } \\
\text { margin trading }\end{array}$ \\
\hline 4 & $\begin{array}{l}\text { Pelaporan dan } \\
\text { Keter-bukaan } \\
\text { Informasi }\end{array}$ & $\begin{array}{l}\text { Bila dipandang perlu, DSN-MUI berhak } \\
\text { memperoleh informasi dari Bapepam dan pihak } \\
\text { lain dalam rangka penerapan prinsip syariah di } \\
\text { Pasar Modal. }\end{array}$ \\
\hline
\end{tabular}

Setidaknya terdapat empat belas (14) fatwa yang telah dikeluarkan oleh DSN -MUI yang berhubungan dengan pasar modal syariah sejak tahun $2001{ }^{46}$ Fatwa DSN-MUI berdasarkan hukum Indonesia bukan sebagai sumber hukum dalam hierarki peraturan perundang-undangan, maka fatwa DSN-MUI tersebut perlu diintegrasikan kedalam peraturan Bapepam. ${ }^{47}$ Fatwa MUI tersebut dipenuhi setiap emiten yang akan menerbitkan efek syariah sehingga input dari fatwa tersebut adalah dikelurakannya Daftar Efek Syariah (DES). DES yang diterbitkan Bapepam- LK dapat dikategorikan menjadi 2 jenis yaitu: ${ }^{48}$

1. DES Periodik

DES Periodik merupakan DES yang diterbitkan secara berkala yaitu pada akhir Mei dan November setiap tahunnya. DES Periodik pertama kali diterbitkan Bapepam-LK pada tahun 2007.

2. DES Insidentil

DES insidentil merupakan DES yang diterbitkan tidak secara berkala. DES Insidentil diterbitkan antara lain yaitu:

- Penetapan saham yang memenuhi kriteria efek syariah syariah bersamaan dengan efektifnya pernyataan pendaftaran Emiten yang melakukan penawaran umum perdana atau pernyataan pendaftaran Perusahaan Publik.

- Penetapan saham Emiten dan atau Perusahaan Publik yang memenuhi kriteria efek syariah berdasarkan laporan keuangan berkala yang disampaikan kepada Bapepam-LK setelah Surat Keputusan DES secara periodik ditetapkan.

${ }^{46}$ Edi Hudiata, Jurna Hukum dan Peradilan, Rekontruksi Hukum Penyelesaian Sengketa Pasar Modal Syariah: Penguatan Aspek Regulasi Untuk Memberikan Kepastian Hukum, Vol 6 No 2, Juli 2017

${ }^{47}$ Ibid

48 Otoritas Jasa Keuangan, Pengantar Daftar Efek Syariah, https://www.ojk.go.id /id/kanal/syariah/data-dan-statistik/daftar-efek-syariah/default.aspx 
Saat ini mengenai Daftar Efek Syariah, secara priodik dikeluarkan oleh OJK. Berikut beberapa aturan terbaru mengenai Daftar Efek Syariah yang dikeluarkan OJK: ${ }^{49}$

- Keputusan Dewan Komisioner OJK Nomor KEP-29/D.04/2019 tentang Daftar Efek Syariah

- Keputusan Dewan Komisioner OJK Nomor KEP-72/D.04/2018 tentang Daftar Efek Syariah

- Keputusan Dewan Komisioner OJK Nomor KEP-24/D.04/2018 tentang Daftar Efek Syariah

- Keputusan Dewan Komisioner OJK Nomor KEP-59/D.04/2017 tentang Daftar Efek Syariah

- Keputusan Dewan Komisioner OJK Nomor KEP-19/D.04/2017 tentang Daftar Efek Syariah

- Keputusan Dewan Komisioner OJK Nomor KEP-56/D.04/2016 tentang Daftar Efek Syariah

- Keputusan Dewan Komisioner OJK Nomor KEP-22/D.04/2016 tentang Daftar Efek Syariah

- Keputusan Dewan Komisioner OJK Nomor KEP-63/D.04/2015 tentang Daftar Efek Syariah

- Keputusan Dewan Komisioner OJK Nomor KEP-34/D.04/2015 tentang Daftar Efek Syariah

Fatwa DSN inilah yang dapat memberikan informasi terkait dengan kondisi emiten didalam pasar modal syariah apakah masih terdapat didalam list DSN MUI ataukah sudah keluar dari list tersebut. Jika keluar, berarti kegiatan bisnis emiten telah menyimpang dari kriteri-kriteria yang ditetapkan DSN MUI sebagai kegiatan bisnis yang menerapkan prinsip syariah.

${ }^{49}$ Data Produk Daftar Efek Syariah, http://www.ojk.go.id/id/kanal/syariah /data-danstatistik/daftar-efek-syariah/default.aspx 


\section{Perlindungan Konsumen Selaku Investor Terhadap Praktik Bisnis Emiten Didalam Pasar Modal Syariah}

Pasal 1 butir 2 Undang Undang No 8 Tahun 1999 tentang Perlindungan Konsumen (UU Perlindungan Konsumen menjelaskan bahwa: ${ }^{50}$

Konsumen adalah Konsumen adalah setiap orang pemakai barang dan/atau jasa yang tersedia dalam masyarakat, baik bagi kepentingan diri sendiri, keluarga, orang lain, maupun makhluk hidup lain dan tidak untuk diperdagangkan

Mengacu pada pengertian tersebut, dapat diartikan konsumen berada pada posisi selaku pemakai barang atau jasa. Pada ruang lingkup kegiatan investasi di pasar modal, konsumen dikategorikan sebagai investor selaku pengguna jasa yang disediakan emiten dalam bentuk efek. Sehingga perlu dijamin perlindungan hukum bagi konsumen dengan mengedepankan prinsip perlindungan konsumen dalam setiap kegiatan investasi di pasar modal yang dilakukan investor. Perlindungan ini bertujuan agar setiap investor memperoleh keadilan dalam praktik investasi yang dilakukannya sebagaimana diterangkan didalam penjelasan ayat 2 Undang Undang Perlindungan Konsumen yang berbunyi: ${ }^{51}$

"Asas kepastian hukum dimaksudkan agar baik pelaku usaha maupun konsumen menaati hukum dan memperoleh keadilan dalam penyelenggaraan perlindungan konsumen, serta negara menjamin kepastian hukum."

Perlindungan investor menjadi isu yang sangat penting dalam pengembangan sektor keuangan, termasuk pasar modal. Baik itu didalam pasar modal konvensional maupun pasar modal syariah, Investor memiliki peranan yang sangat penting sebagai pelaku utama di bursa. Maju mundurnya suatu pasar modal tergantung besar kecilnya investor. Investor terdiri dari investor lembaga (dana

\footnotetext{
${ }^{50}$ Indonesia, Undang Undang Perlindungan Konsumen, Ps. 1 butir 2

${ }^{51}$ Lihat Penjelasan Ps.2 Undang Undang Perlindungan Konsumen
} 
pensiun, asuransi, reksa dana dan sebagainya) disamping investor individu atau perorangan. $^{52}$

Para investor di dunia pasar modal memiliki preferensi yang berbeda beda satu sama lainnya. ${ }^{53}$ Untuk dapat mengidentifikasi investor, dapat menggunakan model utilitas yang diharapkan yang menyatakan bahwa para pemodal memilih suatu kesempatan investasi yang memberikan utilitas yang diharapkan tertinggi. ${ }^{54}$ Khusus untuk pasar modal syariah, selain juga memperhitungkan utility, juga memperhitungkan risiko apakah suatu bisnis kegiatan usaha tersebut bertentangan atau tidak dengan prinsip syariah.

Salah satu bentuk investasi investor pada pasar modal syariah adalah membeli sekuritas syariah. Sekuritas syariah mencakup saham syariah, obligasi syariah (sukuk), dan reksadana syariah. Investasi dengan pemilikan sekuritas syariah dapat dilakukan di pasar modal syariah, baik secara langsung pada saat penawaran perdana, maupun melalui transaksi perdagangan pasar sekunder di bursa. ${ }^{55}$ Pasar modal yang berbasis syariah baik sistem maupun produk merupakan salah satu jawaban yang diberikan oleh pemerintah dalam upaya memfasilitasi kebutuhan masyarakat sebagai alternative media investasi. ${ }^{56}$ Karenanya setiap pihak wajib mendukung kesuksesannya baik itu investor maupun perusahaan sebagai emiten.

Dalam rangka perlindungan investor, untuk itu setiap perusahaan yang bermaksud menawarkan efeknya dipasar modal harus memberikan informasi atau fakta penting dan relevan mengenai peristiwa, kejadian, atau fakta yang dapat mempengaruhi harga efek di bursa dan atau keputusan investor,calon investor atau

${ }^{52}$ Aristides Katopo dkk, Pasar Modal Indonesia: retrospeksi lima tahun swastanisasi BEJ, Cetakan Pertama, Pustaka Sinar Harapan, Jakarta, 1997, hlm 137

${ }^{53}$ Nurul Huda \& Mustafa Erwin Nasution, Investasi Pada Pasar Modal Syariah, Cetakan kedua, Prenada Media Grup, Jakarta, 2007, hlm. 10-11

${ }^{54}$ Ibid,hlm. 11

${ }^{55}$ Ali Amin Isfandiar, Jurnal Hukum Islam (JHI), Akad Muamalah di Pasar Modal Syariah, Vol 7 No 1, Juni 2009

${ }^{56}$ Nur Maharani, Jurnal Modernisasi, Pasar Modal Syariah Dalam Tinjauan Filosofis Teroris dan Praktis, Vol 2 No 2, Juni 2006 
pihak lain yang berkepentingan atas informasi atau fakta tersebut. ${ }^{57}$ Keterbukaan ini disebut dengan prinsip keterbukaan (disclosure principle). Dari sisi ranah perlindungan konsumen, prinsip keterbukaan ini merupakan perwujudan ketentuan pasal 4 ayat 3 UU Perlindungan konsumen yang berbunyi:

konsumen barang maupun jasa berhak atas informasi yang benar, jelas, dan jujur mengenai kondisi barang dan/atau jasa yang digunakan.

Di Indonesia, khusus untuk pasar modal syariah, selain adanya keterbukaan informasi dari perusahaan, terdapat pengawasan Majelis Ulama Indonesia melalui Dewan Syariah Nasional (DSN). Dalam rangka pengawasan pelaksanaan pemberian produk dan jasa keuangan oleh lembaga keuangan, Dewan Syariah Nasional Akan menunjuk Dewan Pengawas Syariah untuk tiap lembaga bersangkutan. ${ }^{58}$ Peran Dewan Syariah Nasional dan Dewan Pengawas Syariah memang tidak terbatas pada pemberian Fatwa atas produk, jasa dan transaksi keuangan yang akan dilakukan oleh lembaga keuangan, tetapi juga harus menentukan proses purifikasi dan memonitor pengelolaan lembaga keuangan, ${ }^{59}$

Ketentuan mengenai peranan Dewan Pengawas Syariah diatur didalam pasal 109 Undang Undang No 40 Tahun 2007 Perseroan Terbatas mengemukakan bahwa: ${ }^{60}$

1. Persoran yang menjalankan kegiatan usaha berdasarkan prinsip syariah selain mempunyai Dewan Komisaris, wajib mempunyai Dewan Pengawas syariah.

2. Dewan Pengawas Syariah sebagaimana yang dimaksud pada ayat (1) terdiri atas seorang ahli syariah atau lebih yang diangkat oleh Rapat Umum Pemegang Saham atas rekomendasi Majelis Ulama Indonesia

3. Dewan Pengawasa Syariah sebagaimana dimaksud pada ayat (1) bertugas memberikan nasihat dan saran kepada direksi serta mengawasi kegiatan Perseroan agar sesuai dengan Prinsip Syariah.

\footnotetext{
${ }^{57}$ Abdul Halim Barkatullah, Jurnal Cakrawala PMIH, Penerapan Prinsip Keterbukaan Dalam Pasar Modal Syariah Indonesia ,17 Februari 2014

${ }^{58}$ Adrian Sutedi, op.cit., hlm. 236

${ }^{59}$ Ibid

${ }^{60}$ Indonesia, Undang-Undang Tentang Perseroan Terbatas, UU No 40 Tahun 2007, LN
} No. 106 Tahun 2007, TLN 4756. Ps 109 
Selain adanya dewan pengawas syariah, perlindungan investor dari penyimpangan praktik bisnis yang bertentangan dengan prinsip syariah dapat dilakukan dengan adanya informasi secara berkala melalui Daftar Efek Syariah (DES) yang diterbitkan oleh OJK. Melalui DES ini emiten dapat selalu memantau apakah emiten yang menerbitkan efek syariah investor masih terdaftar di list DES atau sudah keluar dari list DES. Dengan demikian investor dapat mengetahui apakah efek yang dimilikinya masih masuk kategori syariah atau tidak.

Berdasarkan hal yang telah dikemukakan, implementasi perlindungan konsumen sebagai pemegang efek syariah di pasar modal syariah adalah melalui keterbukaan informasi secara berkala melalui DES dan pengawasan yang dilakukan pengawas syariah dalam setiap kegiatan usaha yang dilakukan emiten. Namun dilain hal, keterbukaan informasi ini belum menjamin keberlangsungan bisnis emiten akan selalu berada pada koridor syariah. Pemerintah belum memberikan suatu regulasi yang mengharuskan emiten ketika melakukan bisnisnya dalam ranah syariah, harus selalu berupaya menjalankan bisnisnya pada koridor syariah.

Pada saat ini, labelisasi sebagai emiten yang menerbitkan efek syariah seolah hanya sebatas labelisasi yang sama sekali tidak mengikat emiten. Tidak ada jaminan emiten akan selalu berada dalam koridor syariah selamanya. Padahal investor pemegang efek syariah tentu ingin suatu bisnis yang pasti yang akan selalu menerapkan prinsip syariah dalam kegiatan muamalahnya. Maka sangat diperlukan peran pemerintah melalui regulasinya dalam rangka melindungi investor. Seperti melalui pemberian sanksi berupa pemberian ganti kerugian kepada investor bagi emiten yang keluar dari DES .

Menurut Widioatmodjo, kerugian dalam investasi saham adalah Capital loss yaitu kerugian dari hasil jual/beli saham berupa selisih antara nilai jual yang lebih rendah daripada nilai beli saham. ${ }^{61}$ Mengacu pada pendapat Widiotamodjo, kerugian dalam bentuk Capital loss yang mesti mendapat perhatian ketika suatu

${ }^{61}$ Bagus Sujatmiko, Padjajaran Jurnal Ilmu Hukum, Perlindungan Hukum Investor Pasar Modal Akibat Kepailitan Perusahaan Terbuka Ditinjau dari Hukum Kepailitan dan Hukum Perusahaan Indonesia, Vol 2 No 2, tahun 2015 
emiten keluar dari Daftar Efek Syariah. Pada posisi ini, investor yang tujuannya mencari prinsip syariah dalam berinvestasi terpaksa melepas efek yang dimiliki karena tidak masuk dalam kategori efek syariah. Investor terpaksa menjual efeknya tanpa mempertimbangkan unsur keuntungan maupun kerugian. Ini dikarenakan tujuannya semata mata hanya ingin berinvestasi pada kegiatan bisnis yang tidak menyimpang dari prinsip syariah. Sehingga mau tidak mau investor harus menerima resiko kerugian ketika ia melepas sahamnya pada harga dan waktu yang tidak tepat.

\section{KESIMPULAN DAN SARAN}

\section{Kesimpulan}

a. Penerapan Prinsip Keterbukaan di Pasar Modal Syariah tidak jauh berbeda degan Pasar Modal Konvensional. Prinsip keterbukaan tersebut menekankan pada pemberian akses informasi yang lengkap dan akurat mengenai informasi tentang emiten dan perbuatan bisnisnya. Hanya saja terdapat perbedaan dengan adanya Daftar Efek Syariah yang dikeluarkan oleh OJK sebagai tambahan informasi apakah kegiatan bisnis emiten sejalan dengan prinsip syariah atau tidak.

b. Perlindungan hukum bagi konsumen selaku Investor terhadap praktik bisnis emiten diwujudkan dalam bentuk adanya Dewan Pengawas Syariah dan Informasi secara berkala oleh OJK melalui Daftar Efek Syariah. Dewan Pengawas Syariah akan mengawasi praktik bisnis perusahaan agar selalu berada pada koridor syariah. Sedangkan Daftar Efek Syariah yang dikeluarkan oleh OJK berfungsi sebagai acuan bagi konsumen selaku pemegang efek syariah apakah perusahaan masih menjalankan praktik bisnis secara syariah atau tidak.

\section{Saran}

a. Seharusnya pemerintah harus bisa mengikat emiten yang telah berada pada Daftar Efek Syariah untuk selalu menjalankan kegiatan usahanya berdasarkan prinsip syariah. Hal ini tidak terlepas dari salah satu keinginan konsumen membeli efek syariah adalah tidak hanya mencari keuntungan, 
melainkan ingin berinvestasi sesuai syariah islam. Keluarnya emiten dari Daftar Efek Syariah, menyebabkan pemegang efek terpaksa menjual sahamnya yang bukan didasarkan atas untung rugi, melainkan karena tidak mau melakukan kegiatan investasi yang tidak sesuai syariah islam

b. Pasar modal syariah memiliki pangsa pasar yang besar di Indonesia. Untuk itu, pemerintah harus gencar melakukan promosi agar meningkatkan minat kaum muslim di Indonesia untuk berinvestasi. Peningkatan investasi ini akan memberikan keuntungan bagi perekonomian negara. 


\section{DAFTAR PUSTAKA}

\section{Buku}

Billah, Mohd Ma'sum, Penerapan Pasar Modal Islam, Sweet \& Maxwell Asia, Selangor, 2010

Hariyani, Iswi \& Sefrianto Purnomo, Buku Pintar Hukum Bisnis Pasar Modal Strategi Tepat Investasi Saham, Obligasi, Waran, Right, Opsi, Reksadana, \& Produk Pasar Modal Syariah, visimedia, jakarta, 2010

HS, Salim \& Budi Sutrisno, Hukum Investasi Di Indonesia, Cetakan Keempat, Rajawali Pers, Jakarta, 2014

Huda, Nurul \& Mustafa Erwin Nasution, Investasi Pada Pasar Modal Syariah, Cetakan kedua, Prenada Media Grup, Jakarta, 2007

Katopo,Aristides dkk, Pasar Modal Indonesia: retrospeksi lima tahun swastanisasi BEJ, Cetakan Pertama, Pustaka Sinar Harapan, Jakarta, 1997

Mamudji, Sri, Metode Penelitian dan Penulisan Hukum, Badan Penerbit Fakultas Hukum Universitas Indonesia, Jakarta, 2005

Nasarudin, M.Irsan dkk, Aspek Hukum Pasar Modal Indonesia, Cetakan Kedelapan, Kencana Prenadamedia Group, Jakarta, 2014

Saliman, Abdul R, Hukum Binis Untuk Perusahaan Teori dan Contoh Kasus, Cetakan Kesembilan, Prenamedia Grup, Jakarta, 2005

Soekanto, Soerjonoe dan Sri Mamudji. Penelitian Hukum Normatif: Suatu Tinjauan Singkat, Rajagrafindo Persada,Jakarta , 2003

Sugono, Bambang, Metodologi Penelitian Hukum, Raja Grafindo Persada, Jakarta, 2007

Sutedi, Adrian, Pasar Modal Syariah, Cetakan Petama, Sinar Grafika, Jakarta, 2011

\section{Peraturan Perundang Undangan}

Undang-Undang Nomor 40 Tahun 2007 tentang Perseroan Terbatas

Undang Undang Nomor 25 Tahun 2007 tentang Penanaman Modal

Undang Undang Nomor 8 Tahun 1999 tentang Perlindungan Konsumen

Undang Undang Nomor 8 Tahun 1995 tentang Pasar Modal 


\section{Arikel/Jurnal}

Barkatullah, Abdul Halim, Jurnal Cakrawala PMIH, Penerapan Prinsip Keterbukaan Dalam Pasar Modal Syariah Indonesia ,17 Februari 2014

Hudiata, Edi, Jurna Hukum dan Peradilan, Rekontruksi Hukum Penyelesaian Sengketa Pasar Modal Syariah: Penguatan Aspek Regulasi Untuk Memberikan Kepastian Hukum, Vol 6 No 2, Juli 2017

Isfandiar, Ali Amin, Jurnal Hukum Islam (JHI), Akad Muamalah di Pasar Modal Syariah, Vol 7 No 1, Juni 2009

Maharani, Nur, Jurnal Modernisasi, Pasar Modal Syariah Dalam Tinjauan Filosofis Teroris dan Praktis, Vol 2 No 2, Juni 2006

Nazir, Ahmad, S.Sos., M.Si Jurnal HUKAMUNA, Pasar Modal Syariah di Indonesia, Vol. 1 No. 2 Desember 2016

Sujatmiko, Bagus, Padjajaran Jurnal Ilmu Hukum, Perlindungan Hukum Investor Pasar Modal Akibat Kepailitan Perusahaan Terbuka Ditinjau dari Hukum Kepailitan dan Hukum Perusahaan Indonesia, Vol 2 No 2, tahun 2015 Rafles, Inovatif Jurnal Ilmu Hukum, Analisis Penerapan Prinsip Keterbukaan di Pasar Modal Dalam Kaitannya Dalam Pengelolaan Perusahaan Yang Baik, Vol 8 No 1, 15 Maret 2016

\section{Internet}

Ana Noviani, Harian Bisnis,com, Sebelas Emiten Terdepak dari Daftar Efek Syariah edisi 29 November 2016, http://market.bisnis.com Ardan Adhi Chandra, Investasi Syariah Masih Minim, OJK Sosialisasi ke Pengajian Hingga Pesantrean, Selasa 14 Juni 2016, finance.detik.com 
Harian Ekonomi Kompas 30/10/2017, BEI: Potensi Pasar Modal Syariah di Indonesia Masih Sangat Besar, ekonomi.kompas.com 
118 ADIL: Jurnal Hukum Vol.10 No.2 